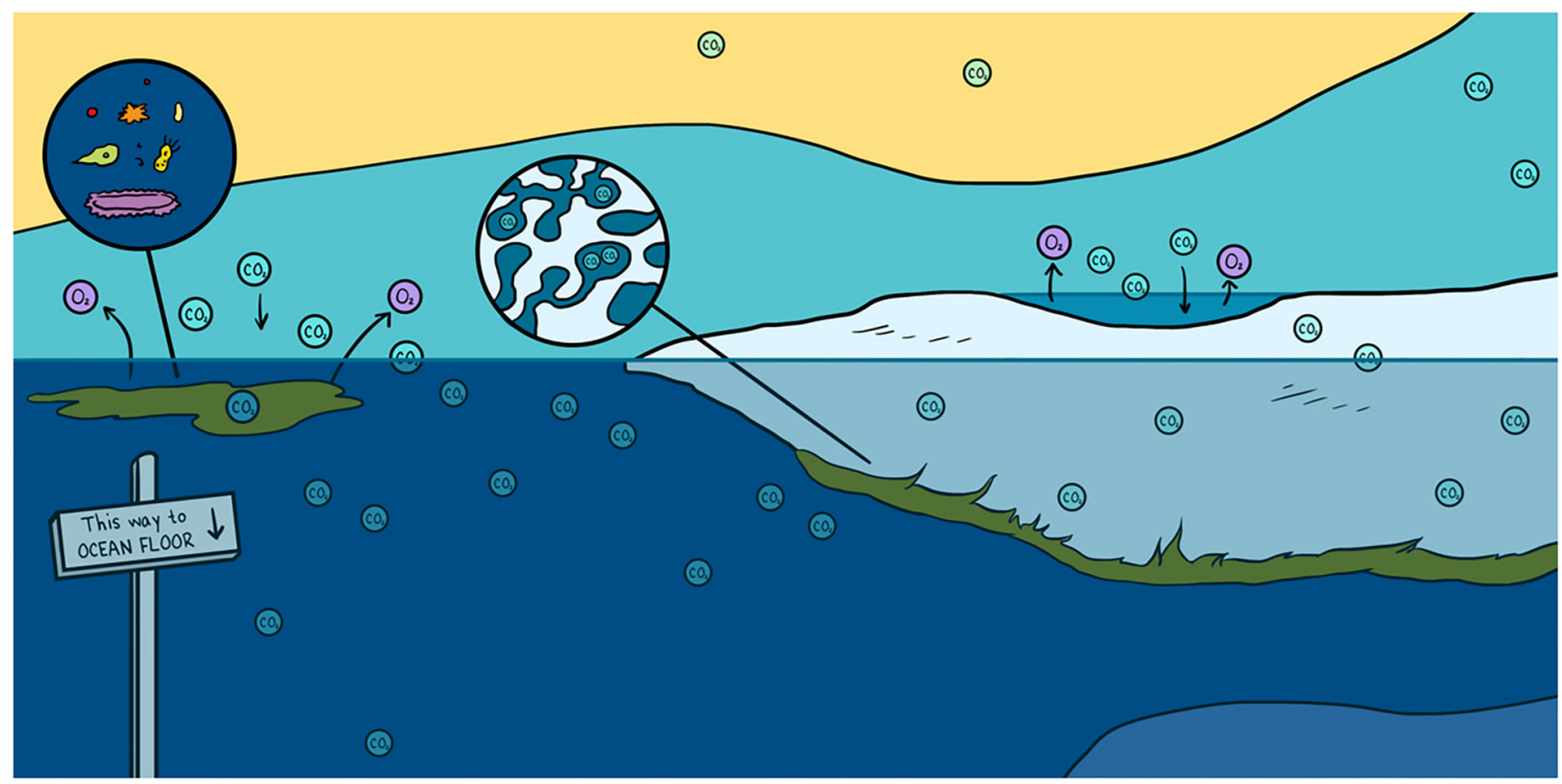

\title{
THE MOVEMENT OF CO2 THROUGH THE FROZEN WORLD OF SEA ICE
}

\author{
Odile Crabeck ${ }^{1,2,3^{*}}$, Karley Campbell ${ }^{4,5}$, Sebastien Moreau ${ }^{6}$ and Max Thomas ${ }^{1}$ \\ ${ }^{1}$ Centre for Ocean and Atmospheric Science, University of East Anglia, Norwich, United Kingdom \\ ${ }^{2}$ Chemical Oceanography Unit, Université de Liège, Liege, Belgium \\ ${ }^{3}$ Laboratoire de Glaciologie, Université Libre de Bruxelles, Brussels, Belgium \\ ${ }^{4}$ Department of Arctic and Marine Biology, The Arctic University of Norway, Tromsø, Norway \\ ${ }^{5}$ Bristol Glaciology Centre, University of Bristol, Bristol, United Kingdom \\ ${ }^{6}$ Biodiversity Department, Norwegian Polar Institute, Tromsø, Norway
}

YOUNG REVIEWER:

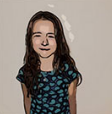

JULIETA

AGE: 9
Every winter, a frozen blanket known as sea ice completely covers the Arctic Ocean. For centuries, sea ice has been viewed as a solid lid on the ocean that acts as a boundary to block gases traveling between the ocean and the atmosphere. However, scientific discoveries over recent years have shown that sea ice is more like a sponge, a porous substance that is also home to microscopic life forms. The pores in sea ice are filled with very salty liquid called brine that is rich in carbon dioxide $\left(\mathrm{CO}_{2}\right)$. These liquid pockets create a network of tubes or channels that move gases like $\mathrm{CO}_{2}$, similar to the way veins and arteries move blood in our bodies. In this article, you will discover how $\mathrm{CO}_{2}$ enters, exits, and is transformed in one of the harshest environments on Earth. 
Figure 1

The seasonal sea-ice cycle in the Arctic. The orange line shows the monthly historical average from 1979 to 1990. The red line shows 2012, when the ice reached a record minimum. 2019 is shown in blue. The left insert shows the sea ice cover at the end of the winter 2019 and the right insert shows it at the end of the summer. Since 2000, the summer sea ice extent has drastically decreased. Maps and date are from the National Snow and Ice Data Center (NSIDC), University of Colorado, Boulder, CO.

\section{SEA ICE}

Is frozen seawater that floats on the ocean surface. It is composed of ice crystal and salty liquid pocket called brine.

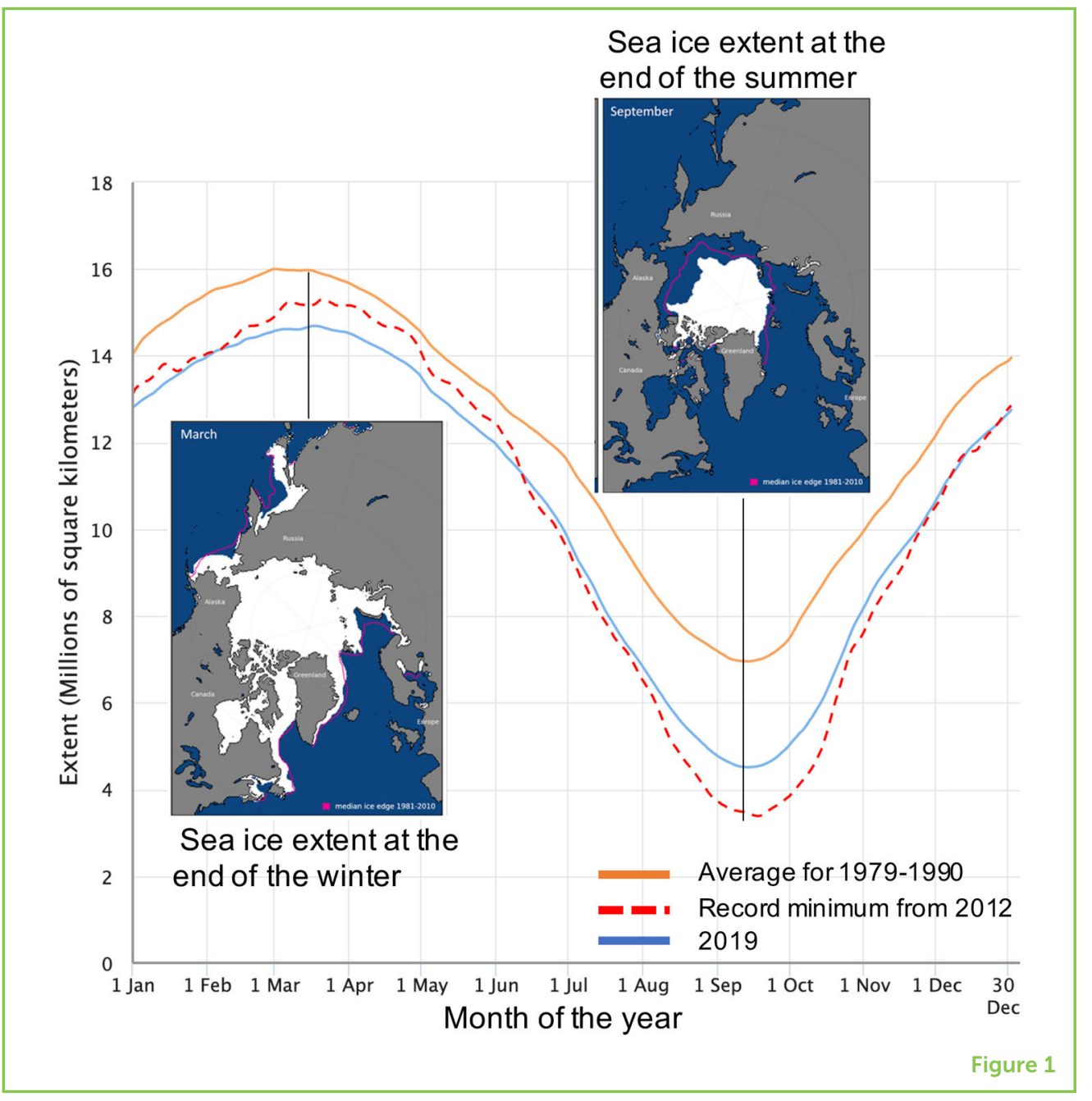

\section{SEA ICE: A ZOOMED-OUT VIEW}

On average, sea ice covers about 23 million square kilometers of the Earth's oceans, or about two-and-a-half times the area of Canada [1]. Due to its size, sea ice is visible from space as a large white blanket on the ocean. By observing sea ice at these vast scales, we can see dramatic changes to the ice extent throughout the year and over decades-since 1978, when the first satellite observations of sea ice were made.

Each year, as the sun sets and winter begins in the Arctic Ocean (in the far North) or the Southern Ocean (in the far South of Antarctica), sea ice forms when air temperatures decrease, and the ocean begins to freeze. As winter continues, sea ice thickens and grows outwards to cover vast areas of the ocean. In some places in the Arctic, sea ice even grows to be many meters thick! As the sun rises and the air warms in the spring, the sea ice begins to melt and break up, exposing the liquid ocean below. We call this expansion and contraction of sea ice a seasonal cycle (Figure 1). 
BRINE

Is water with a high concentration of dissolved salt.

\section{SOLUBILITY PUMP}

Is a process that takes up $\mathrm{CO}_{2}$ from the atmosphere to the ocean's surface as dissolved $\mathrm{CO}_{2}$ and transports it to the bottom of the ocean.

\section{BIOLOGICAL PUMP}

Contributes to the ocean's role in taking up and storing $\mathrm{CO}_{2}$ from the atmosphere. The $\mathrm{CO}_{2}$ is transformed and stored by micro-organism as algae that use photosynthesis to grow.
Comparing sea ice from year to year, we find that the amount of sea ice covering the ocean is changing. This long-term change is happening as the sea ice continues to grow and melt as part of its yearly seasonal cycle (Figure 1, blue and orange lines). In the Arctic, sea ice is melting more in summer than it used to, and we have already lost 30\% of the summer sea ice since 1990 (Figure 2, yellow line). Scientists predict that, by 2050, all the Arctic sea ice will completely melt during summer for the first time in history. This means that, although explorers can walk to the North Pole today, in the future they will have to sail to it. One of the great research questions of our time is how these changes are affecting ocean life and our warming climate.

\section{SEA ICE: A CLOSER LOOK}

Zooming in on sea ice, to the scale of only a few centimeters, shows that it is complex. Pockets of salty liquid, known as brine, exist in the sea ice (Figure 2). Brine pockets are liquid at temperatures below zero because the salt prevents the liquid from freezing, and there is always some liquid in sea ice [2]. Zooming in still further we find gas bubbles, salt crystals, and life within these brine pockets (Figure 2, bottom panel). These brine pockets are a unique habitat for microscopic organisms and a place where chemical reactions happen. Scientists have been working to understand sea ice at these very small scales and see how sea ice affects the chemical nature of the oceans and even life beyond the oceans.

\section{$\mathrm{CO}_{2}$ IN THE ATMOSPHERE, OCEANS, AND LIVING ORGANISMS}

Carbon is one of the most abundant elements on Earth, along with oxygen, nitrogen, and hydrogen. Carbon is found in the atmosphere as carbon dioxide $\left(\mathrm{CO}_{2}\right)$ gas, in the ocean as dissolved $\mathrm{CO}_{2}$, in some kinds of rock, and in all living organisms. Carbon is essential to life and you are made of about $20 \%$ carbon.

In the atmosphere, $\mathrm{CO}_{2}$ is a major gas that contributes to global warming [3]. $\mathrm{CO}_{2}$ emitted by human activities (cars, the oil/gas industry, etc.) can move between the atmosphere, the oceans, and living organisms, and it changes forms as it moves. If $\mathrm{CO}_{2}$ is pumped into the deep ocean, it can be locked up there for hundreds of years, reducing global warming. The processes that move $\mathrm{CO}_{2}$ from the atmosphere into the ocean are called pumps. There are two main $\mathrm{CO}_{2}$ pumps in the ocean: the solubility pump and the biological pump. Oceans have already absorbed one-third of the $\mathrm{CO}_{2}$ emitted by human activities thanks to the solubility and biological pump.

The solubility pump (Figure 3, blue arrows) refers to the process by which atmospheric $\mathrm{CO}_{2}$ is absorbed by the ocean surface and become 
Figure 2

Sea ice a closer look. On the top panel, a satellite view of the Arctic Ocean at the end of summer 2019. The yellow line shows the historical (1979 to 1990) extent of the sea ice summer cover. We can observe that there is now less ice in the Arctic during the summer. Before the summer sea ice cover was reaching beyond the yellow line. The middle panel shows scientists sampling sea ice during the summer season. The bottom panel shows on the left-side the sea ice internal structure and on the right-side, ice cores that contain a lot of algae at the bottom. This bottom panel shows also, where the $\mathrm{CO}_{2}$ is trapped in sea ice:

1. In brine where the $\mathrm{CO}_{2}$ is stored in a dissolved state,

2. In bubbles where the $\mathrm{CO}_{2}$ is stored in gas phase,

3. In crystals of calcium carbonate where the $\mathrm{CO}_{2}$ is stored in solid form as rocks,

4. In sea ice algae where the $\mathrm{CO}_{2}$ is stored as carbon (sugars food) (http://www. arcodiv.org/ seaice/diatoms/ IceDiatoms .html).

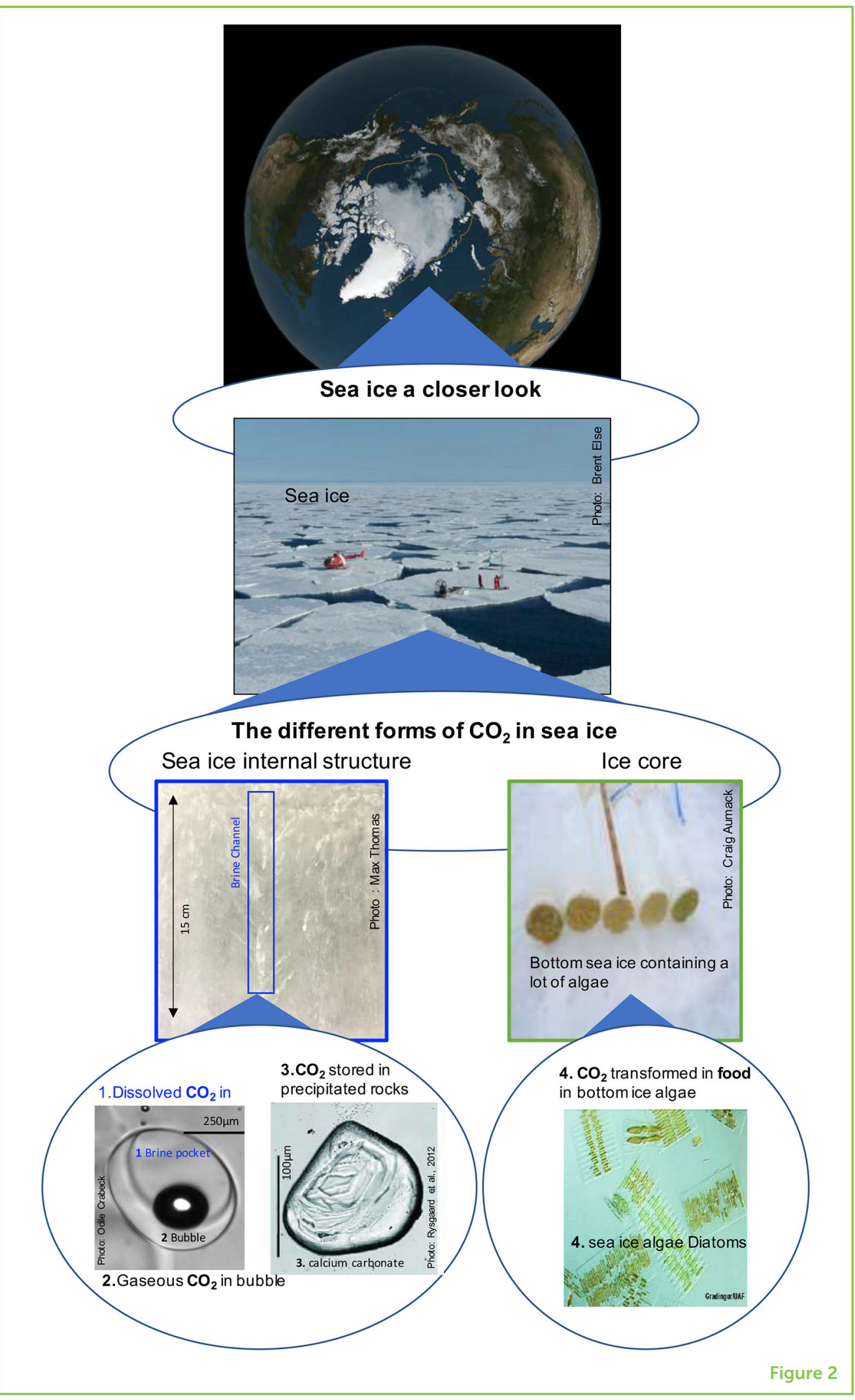

dissolved in the surface ocean. Once the $\mathrm{CO}_{2}$ is dissolved, it can be transported deep into the ocean by the ocean currents. The capacity of the ocean to take up $\mathrm{CO}_{2}$ from the atmosphere depends on the water temperature and salinity (saltiness). Cold, freshwater can absorb 
Figure 3

How does $\mathrm{CO}_{2}$ move from the atmosphere into the ocean? $\mathrm{CO}_{2}$ is found in the

atmosphere as a gas. This $\mathrm{CO}_{2}$ can dissolve in the seawater. Once in the seawater, it can be transported by currents to the bottom of the ocean. We call this the solubility pump (blue arrow). Sea ice can also exchange $\mathrm{CO}_{2}$ with the atmosphere. The $\mathrm{CO}_{2}$ in sea ice is either dissolved in brine or stored as gas in bubble or in solid phase as calcium carbonate rocks. Some of the brine containing $\mathrm{CO}_{2}$ is rejected to the underlying seawater and transported to the interior part of the of the ocean. This process trapped $\mathrm{CO}_{2}$ at the bottom of the ocean for a very long time (white arrow). Sea-ice algae also use $\mathrm{CO}_{2}$ to grow, through the process of photosynthesis. We call this the biological pump (green arrow). The $\mathrm{CO}_{2}$ stores in algae as food can move up the food chain as the algae is eaten by grazers, which are then eaten successively by larger animals.

\section{PHYTOPLANKTON}

Are single-celled algae that live at the surface of the ocean and use the photosynthesis process to grow. The most common types of phytoplankton are Diatoms.

Phytoplankton form the base of aquatic food webs. They are used as food supply by small fish and other marines' animals.

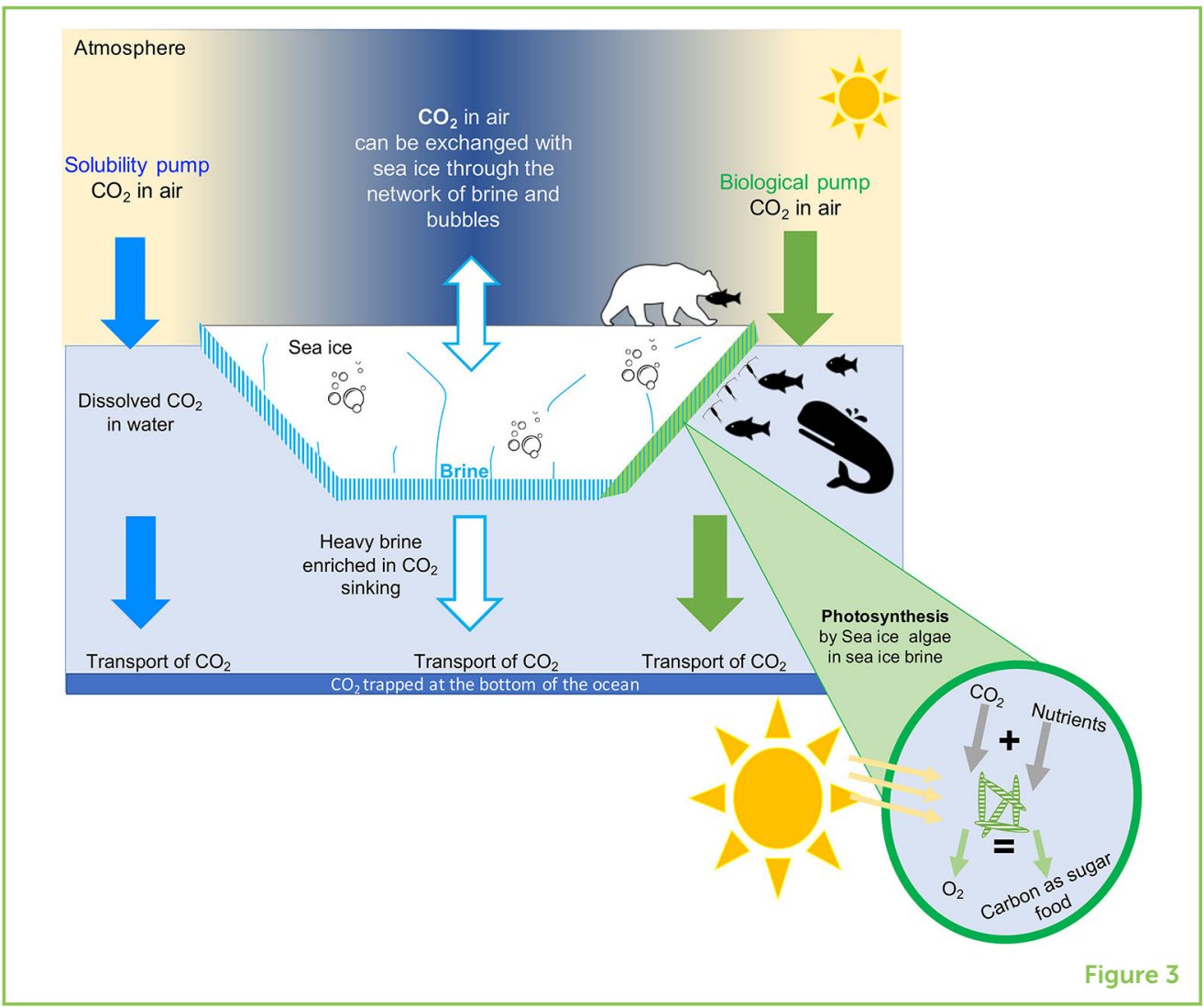

more $\mathrm{CO}_{2}$ than warm, salty water. Therefore, the cold polar oceans, like the Arctic Ocean, are great at taking up $\mathrm{CO}_{2}$ from the atmosphere. If the $\mathrm{CO}_{2}$ goes to the bottom of the ocean, it can stay there for 1000 years or more (Figure 3 ).

The biological pump refers to the use of $\mathrm{CO}_{2}$ by algae called phytoplankton. Algae are microscopic, single-celled organisms that grow using sunlight, nutrients, and $\mathrm{CO}_{2}$ in the chemical process of photosynthesis [4] (Figure 3, green arrows). Many phytoplankton live floating in the world's oceans. Because algae use $\mathrm{CO}_{2}$ to grow, they help the ocean to take up $\mathrm{CO}_{2}$ from the atmosphere (Figure 3, green arrows). Some of these algae are specialized to live in the unique environment provided by sea ice, including in the liquid brines.

\section{HOW DOES SEA ICE ALGAE TRANSFORM CO2?}

I am only as big as a cell. I breathe in $\mathrm{CO}_{2}$ and breath-out $\mathrm{O}_{2}$. I live in salty brine pocket, and I get my energy from the sunlight. Who am I? I am a sea ice algae.

Ice algae grow in brine pockets within the ice, in meltwater ponds at the surface, and most importantly at the base of sea ice, where the ice is touching the ocean below. Ice algae grow quickly, or 


\section{PHOTOSYNTHESIS}

Is the process by which plants and algae make food. This chemical process uses sunlight, $\mathrm{CO}_{2}$, and nutrients to produce sugars that the cell can use as energy to grow.

\section{BLOOM}

Is a rapid increase in the population of algae. An algal bloom is often recognized by the green or brown coloration of the water

\section{CALCIUM}

\section{CARBONATE}

Is a sedimentary rock like limestone. Calcium carbonate is produced by the precipitation (solidification) of dissolved calcium and $\mathrm{CO}_{2}$ in water. bloom, when light becomes available for photosynthesis in the spring (Figure 3, green arrows). Ice algae known as diatoms are very good at growing quickly and largely make-up the ice-algae bloom. Although the diatoms are too small to count individually, scientists can see the bloom as a browning of the ice (Figure 2, bottom panel). The ice-algae bloom lasts until late summer when the cells have used up the nutrients needed to grow and when the ice around them begins to melt. Photosynthesis performed by ice algae can have a large impact on how much $\mathrm{CO}_{2}$ sea ice takes up in the spring (Figure 3, green arrows). Generally, when the ice is brown with algae, it is expected that lots of $\mathrm{CO}_{2}$ is being taken up into the ice (Figure 2, bottom panel). Ice algae play an important role in using atmospheric $\mathrm{CO}_{2}$, but they are also important for the animals living in the Arctic Ocean. The growth of ice algae supplies other organisms with a lot of food. The size of the algae bloom means that organisms can get lots of food very easily, like going to a vegetarian buffet for dinner. Nutrition gained from ice algae is transferred up the food web as one organism eats another, all the way to the polar bear.

\section{WHAT HAPPENS TO $\mathrm{CO}_{2}$ TRAPPED IN SEA ICE?}

As sea ice forms in winter, it traps salts and $\mathrm{CO}_{2}$ from the ocean in brine (Figure 2, bottom panel). In fact, so much $\mathrm{CO}_{2}$ gets trapped with salt that it is transformed into solid rock by chemical reactions. One of the most common rocks that forms from $\mathrm{CO}_{2}$ inside sea ice is made of calcium carbonate, also called limestone, which is the same substance that makes up the skeletons of corals and many seashells you might find on the beach. Researchers can see the tiny pieces of calcium carbonate when they melt a core of sea ice and look at it under the microscope (Figure 2, bottom panel). The $\mathrm{CO}_{2}$ in sea ice is also trapped in bubbles (Figure 2, bottom panel). The bubbles can rise from the bottom of the sea ice to the surface through the brine channels. Once at the surface, the gases can escape into the air (Figure 3 , white arrows). Sea ice also sends some $\mathrm{CO}_{2}$ to the bottom of the ocean. This process takes place during winter, when the salty brine from the sea ice sinks to the deep ocean, bringing $\mathrm{CO}_{2}$ along (Figure 3 , white arrows). This is often referred to as the sea-ice pump, similar to the solubility and biological pumps described above. Through the rising bubbles and sinking brine, the sea ice loses a lot of $\mathrm{CO}_{2}$ that was trapped inside it. As a result, when the sun comes back in the spring, the sea ice no longer holds as much $\mathrm{CO}_{2}$. Researchers have observed that, in the spring, sea ice can again absorb lots of $\mathrm{CO}_{2}$ from the atmosphere. Overall, researchers think that sea ice helps the ocean to absorb $\mathrm{CO}_{2}$. So, sea ice helps us fight climate change. 


\section{KEY MESSAGES}

Sea ice cover grows in winter and melts in summer. Thanks to the cold water and the presence of algae and sea ice, the Arctic Ocean is a carbon sink; it helps to decrease the amount of $\mathrm{CO}_{2}$ in the atmosphere. Firstly, sea ice algae use $\mathrm{CO}_{2}$ to grow and create food for larger organisms. Secondly, sea ice can trap $\mathrm{CO}_{2}$ in its brine and favor its transport to the bottom of the ocean. In the Arctic, the summer sea ice cover is strongly decreasing due to global warming. Global warming threatens the house of ice algae and the ability of the Arctic Ocean to exchange $\mathrm{CO}_{2}$ with the atmosphere.

\section{ACKNOWLEDGMENTS}

This work was a contribution to the Diatom-ARCTIC (Diatom Autecological Responses with Changes to Ice Cover) and EISPAC (Effects of ice stressors and pollutants on the Arctic marine cryosphere) project. This work was also supported by the international working group BEPSII: Biochemical exchange processes at Sea Ice Interfaces.

\section{REFERENCES}

1. Thomas, D. N. (Ed.). 2017. Sea Ice. Norwich:John Wiley \& Sons.

2. Glessmer, M. 2019. How does ice form in the sea? Front. Young Minds 7:79. doi: 10.3389/frym.2019.00079

3. Hubbe, A., and Hubbe, M. 2019. Current climate change and the future of life on the planet. Front. Young Minds 7:37. doi: 10.3389/frym.2019.00037

4. Ghosh, T., and Mishra, S. 2017. How does photosynthesis take place in our oceans? Front. Young Minds 5:34. doi: 10.3389/frym.2017.00034

SUBMITTED: 29 November 2019; ACCEPTED: 08 December 2020;

PUBLISHED ONLINE: 20 January 2021.

EDITED BY: Christian März, University of Leeds, United Kingdom

CITATION: Crabeck O, Campbell K, Moreau S and Thomas M (2021) The Movement of $\mathrm{CO}_{2}$ Through the Frozen World of Sea Ice. Front. Young Minds 8:516072. doi: 10.3389/frym.2020.516072

CONFLICT OF INTEREST: The authors declare that the research was conducted in the absence of any commercial or financial relationships that could be construed as a potential conflict of interest.

COPYRIGHT (C) 2021 Crabeck, Campbell, Moreau and Thomas. This is an open-access article distributed under the terms of the Creative Commons Attribution License (CC BY). The use, distribution or reproduction in other forums is permitted, provided the original author(s) and the copyright owner(s) are credited 


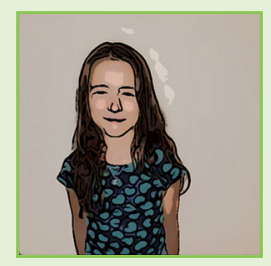

and that the original publication in this journal is cited, in accordance with accepted academic practice. No use, distribution or reproduction is permitted which does not comply with these terms.

\section{YOUNG REVIEWER}

\section{JULIETA, AGE: 9}

$\mathrm{Hi}$, my name is Julieta I was born in Minnesota (United States of America) but now I moved with my family to Uruguay. I speak English and Spanish. I like roller skating and making pottery. At school my favorite subject is Math.

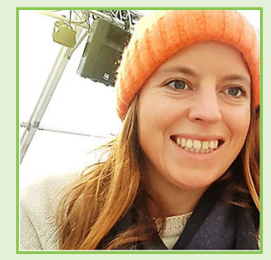

\section{AUTHORS}

\section{ODILE CRABECK}

Odile Crabeck is a research fellow at the Fund for Scientific Research of Belgium, I study the sea ice the physical and biogeochemical state of the sea ice brine and bubbles, using fieldworks data and laboratory studies. *ocrabeck@uliege.be

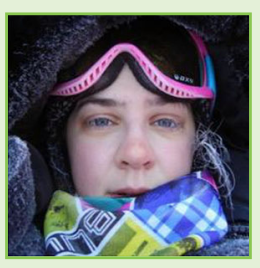

\section{KARLEY CAMPBELL}

Karley Campbell is an Associate Professor of Marine Botany at The Arctic University of Norway, and an affiliated researcher at the University of Bristol, UK. Her research brings together lab and field-based studies to determine how environmental change will affect on sea ice microorganism activity, species composition and physiology.

\section{SEBASTIEN MOREAU}

Sebastien Moreau is a sea ice and ocean biogeochemist working at the Norwegian Polar Institute, Troms $\varnothing$, Norway. His research focuses on phytoplankton and the biogeochemical cycle of carbon of polar oceans. He investigates these questions by using field observations, satellite data as well as 1D and 3D models.

\section{MAX THOMAS}

Max Thomas is a research fellow at the University of Otago, New Zealand. He uses laboratory observations and a range of modeling tools to study sea-ice physics. 